\title{
偏平ドーム状空間骨組構造物の動的崩壊挙動と 吸収エネルギ一に関する考察 \\ ON THE RELATION BETWEEN ABSORBED ENERGY AND DYNAMIC COLLAPSE OF A SINGLE-LAYER SHALLOW LATTICED DOME
}

\author{
喬鋒*, 萩原伸 幸**, 松井徹哉*** \\ Feng QIAO, Nobuyuki HAGIWARA and Tetsuya MATSUI
}

\begin{abstract}
The collapse characteristics of a single-layer shallow latticed dome under vertical dynamic excitation is investigated from the point of view of the absorbed energy. Both static and dynamic analyses are performed taking into account the geometrical and material nonlinearities. By comparing the collapse characteristics under the dynamic excitation and the static distributed loads which are proportional to vibration modes, it is shown that the absorbed energies at the collapse state under both static and dynamic excitations are limited, and that the maximum absorbed energies are different with different vibration modes. This latter is a particular characteristic for the latticed dome which is distinguished from that for the plate-type space frame.
\end{abstract}

\footnotetext{
Keywords: single-layer latticed dome, vibration mode, earthquake response, dynamic collapse, absorbed energy, mode extraction
}

単層ラチスドーム, 振動モード, 地震応答, 動的崩壊, 吸収エネルギー, モード抽出

\section{1. 序}

空間構造物の動的挙動や耐震性能に関する研究が近年盛んに行われる ようになってきており 1) 9)，その応答性状が明らかにされつつある。 特に, 空間構造物の場合は, 構造の形態や形式が多様であることに加え て，固有振動数が接近して存在すること，低次振動モードが必ずしも大 きな刺激関数を与えるとは限らないこと, 上下振動の影響が相対的に重 要になることなど, 特有の振動性状を示すことから, 地震力を層せん断 力に置換する通常の建築構造骨組用耐震設計法を単純に適用することに は困難があると考えられる。現状では, 線形振動解析や, 何らがの工学 的判断に基づいて静的置換された地震荷重を用いて耐震設計が行われる ことが多く，大空間構造に対する合理的な静的地震荷重の算定手法は未 だ確立されていない。

空間構造物の耐震設計に用いる静的地震荷重分布は, その崩壊形状や 弾塑性振動性状などを把握した上で，検討される必要があると考えられ る。空間構造物を対象とした動的な弾塑性崩壊性状に関しては, 加藤ら 8)，が崩壊加速度に注目し，単層ラチスドームの耐震性を固定荷重に対 する安全率との関係に基づいて整理しているほか，多田ら ${ }^{9)}$ が複層平

板立体トラスの崩壊時の吸収エネルギーに着目して, 動的崩壊挙動との 関連について分析を行っている。多田らは, 固定荷重によるポテンシャ ルエネルギー以外に構造物が吸収しうるエネルギーを吸収エネルギーと 定義し，これを動的崩壊の判定指標として用いることを提案している。 さらに, 平板トラスの場合は, 静的漸增載荷時の最大吸収エネルギーが 荷重分布形に鈍感であり，動的崩壊時のそれの下限值を与えるとの結論 を得て, 合理的な設計用地震荷重分布を設定する上で貴重な示唆を与え ている。しかし, 平板立体トラスと違って, ドーム状の構造物の場合は 励起される振動モードにより構造物の崩壊性状が異なり, 崩壊時の最大 吸収エネルギーの值も異ってくると考えられる。さらに, 構造物が動的 外乱を受け塑性化すれば, 固有振動数や振動モードに変化が生じ, 初期 の状態からは予期できないメカニズムによって崩壊に至ることも考えら れる。よって，平板立体トラスを対象として分析された知見が直接ドー ム状の構造物にも適用できるか否かについて検討する必要があると考え られる。

このような観点から, 本論文では, 偏平ドーム状空間骨組構造物の力 学特性を有する簡単な解析モデル限定し, その動的崩壊挙動と吸収エ

* 名古屋大学大学院工学研究科建築学専攻 大学院生・修士 (工学)

** 大同工業大学建設工学科 講師・博士 (工学)

*** 名古屋大学大学院工学研究科建築学専攻 教授・工博
Graduate Student, Dept. of Architecture, Nagoya Univ., M. Eng.

Assist. Prof., Dept. of Construction Eng., Daido Inst. of Technology, Dr. Eng Prof., Dept. of Architecture, Nagoya Univ., Dr. Eng. 
ネルギーとの関連について考察する。特に励起される振動モードが構造 物の崩壊性状と吸収エネルギーに及ほす影響に着目し, 静的荷重分布と つ関連性について分析することにより，平板立体トラスを対象として得 られた知見が偏平ドームに対しても適用できるか否かを検討することを 目的とする。

\section{2. 解析モデルと解析方法}

\section{1. 解析モデル}

解析モテルとして，図 1 に示すような偏平ラチスドームを採用する。 このモテルは偏平ドーム状空間骨組構造物の力学特性を有するモテル としてしばしば採用されるピン接合ドーム10）の接合条件と部材断面 に一部修正を加えたものである。ドームはすべて同一断面の鋼管部材 $(\phi 165.2 \times 5)$ で構成されるものとする。節点における部材の接合を剛 接合とし，境界条件は周辺ピン支持とする。固定荷重として図 1 に示す ように各節点に $P=5 t f$ の集中荷重を与え, 動的解析モテルとして各 節点に固定荷重相当の集中質量を配している。簡単のため, 减衰定数は 0 とする。

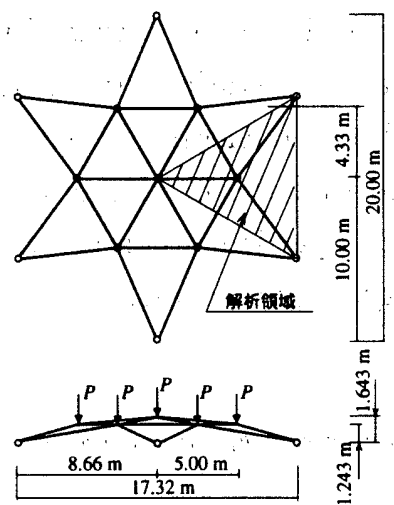

図一 1: 解析モデル

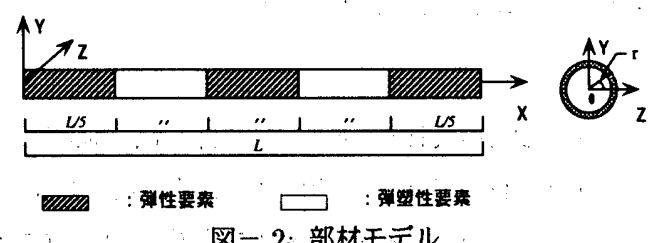

図一2: 部材モデル

“部材モテルは, 図 2 に示すように, 部材端および中央に配置された $3 つ$ 弾塑性立体梁要素とそ机らを䋈く 2 つの弾性立体梁要素により構 成される 11)。“要素座標系として，材軸方向に $\mathrm{x}$ ，断面の主軸方向に $\mathrm{y}$, $\iota$ をとり, $\mathrm{x}, \mathrm{y}, \mathrm{z}$ 方向の変位成分をそれぞれ $u_{x}, u_{y}, u_{z}$ とする。さ らに，梁の断面において，材軸位置を原点とする極座標 $(r, \theta)$ を定義す る。幾何学的非線形性を考慮するため; 要素内の軸方向歪 $\varepsilon$ おびねじ り柾 $\gamma$ を次式で表す。

$$
\begin{aligned}
\varepsilon & =\frac{d u_{x}}{d x}-\frac{d u_{y}^{2}}{d x^{2}} r \sin \theta-\frac{d u_{z}^{2}}{d x^{2}} r \cos \theta+\frac{1}{2}\left(\frac{d u_{y}}{d x}\right)^{2} \\
& +\frac{1}{2}\left(\frac{d u_{z}}{d x}\right)^{2}+\frac{1}{2}\left(\frac{d u_{x}}{d x}-\frac{d u_{y}^{2}}{d x^{2}} r \sin \theta-\frac{d u_{z}^{2}}{d x^{2}} r \cos \theta\right)^{2} \\
\gamma & =r \frac{d \phi}{d x}
\end{aligned}
$$

梁要素の変位関数として, 軸方向変位 $u_{x}$ に関して一次, 回転変位 $\phi$ に関して一次, たわみ方向変位 $u_{y}, u_{z}$ に関して三次の多項式を採用 する。数値皘分には, 弾性要素については軸方向 5 点, 周方向 8 点の Gauss 求積分を使用し，弾塑性要素については軸方向は弾性要素と同様
で, 周方向においては, 断面を均等に 8 分割したセグメントを用いて算 定する。応力一歪関係には完全弾塑性型（初期剛性 $2100 \mathrm{t} / \mathrm{cm}^{2}$, 降伏 応力度 $2.4 \mathrm{t} / \mathrm{cm}^{2}$ ) を用いる。

\section{2. 時刻歷応答解析}

時刻歴応答解析には，材料および幾何学的非線形性を考慮するために Newmark $\beta$ 法（ $\beta=1 / 4 ）$ の增分変位表現による定式化を用いる 11$) 。$ 各增分ステップの残差荷重については，その增分区間内で NewtonRaphson 法により.0に収敛させる。固定荷重が初期棡性に及ぼす影響 を考虑するために，まず固定荷重に対する静的解析を行ない，この状態 に対して動的荷重を作用させ，応答解析を開始する。

\section{3. 吸収エネルギーの定式化}

構造物における系のポテンシャルエネルギーは, 系の内部にある運動 エネルギー $\left(E^{l}\right)$, 减衰による散逸エネルギー $\left(E^{D}\right)$, 構造物の内部工 ネルギー $\left(E^{e}\right)$ と動的外乱あるいは静的外乱によって入力されるエネル キー $\left(E^{F}\right)$, 固定荷重によるポテンシャルエネルギー $\left(E^{G}\right)$ に分類でき る。ここで， $E^{e}-E^{G}$ は固定荷重によるポテンシャルエネルギー以外 に構造物が吸収するエネルギーを表し、多田ら 9) はこれを吸収エネル ギーと定義している。本研究では，静的解析および時刻歴応答解析によ り得られたデータからその構造物の吸収エネルギーを算定する。

静的漸增載荷時および動的外乱時における骨組構造物の釣合式は，減 衰がない時, 式 (2), (3) で表される。

$$
\begin{aligned}
M_{i j} g_{j}-Q_{i}+F_{i} & =0 \\
M_{i j}\left(\ddot{x}_{j}+\ddot{y}_{j}\right)+Q_{i} & =M_{i j} g_{j}
\end{aligned}
$$

ここに, $M_{i j}$ : 質量マトリクス, $g_{j}$ : 重力加速度ベクトル， $\ddot{x}_{j}:$ 質点 の相対加速度ベクトル， $\ddot{y}_{j}$ : 入力加速度ベクトル， $Q_{i}$ : 復元カベクト ル， $F_{i}$ : 固定荷重を除いた荷重ベクトルである。式 $(2),(3)$ の両辺に 変位 $d x_{i}=\dot{x}_{i} d t$ を掛け糟分し整理すると, 式 (4)，(5) を得る。

$$
\begin{gathered}
\int_{0}^{d} Q_{i} d x_{i}-\int_{0}^{d} M_{i j} g_{j} d x_{i}=\int_{0}^{d} F_{i} d x_{i} \\
\int_{0}^{t} Q_{i} \dot{x}_{i} d t-\int_{0}^{t} M_{i j} g_{j} \dot{x}_{i} d t=-\int_{0}^{t} M_{i j} \ddot{y}_{j} \dot{x}_{i} d t \\
-\int_{0}^{t} M_{i j} \ddot{x}_{j} \dot{x}_{i} d t
\end{gathered}
$$

式 (4), (5) は静的漸増載荷時および動的外乱時のエネルギーの釣合 いを与える。両式の左辺は, 構造物の内部エネルギー $E^{e}$ から固定荷重 のポテンシャル $E^{G}$ を差し引いたものとその時刻歴過程を表しており,

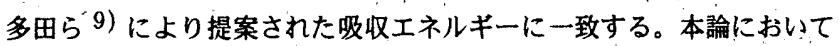
は, 静的解析については式 (4) 右辺で, 動的解析については式 (5) 右辺 でラチスドームの吸収エネルギーを算定している。

\section{4. モード抽出}

本研究では, 滝澤 12) によって提案された手法により, 時刻歴応答 解析によって得られた变位応答データからその構造物の振動モードを推 定する。これによって塑性化に伴う構造物の動的特性と変形性状の変化 
が詳細に把握される。これはあるべクトル時系列 $\{f(t)\} に$ 対して

$$
\{f(t)\} \simeq\{X\} \xi(t)
$$

となるようなモード形 $\{X\}=\left\{u_{x}, u_{y}, u_{z}\right\}^{T}$ を見い出すために, 次式

$$
E=\int_{t_{0}}^{t_{1}}[\{f(t)\}-\{X\} \xi(t)]^{T}[A][\{f(t)\}-\{X\} \xi(t)] d t
$$

を最小化にするものである。ここに, $[A]$ は重みを与える正值対称行列 であり，本解析においては質量マトリクスを用いている。

\section{3. 解析例}

本稿で扱うようなライズが低いドームに対しては水平動より上下動 の影響が大きいと考え, 上下方向の入力に対する崩壊性状に限って検討 する。ここでは軸対称上下振動のみを扱うものとし, 対称性を考虑して 図 1 の斜線部に示される $1 / 6$ の領域について解析を行う。ただし, 水 平あるいは上下地震動によって大規模ドームの一部が面外方向に振動し 局部崩壊するような場合には，ここでの検討で得られた知見が適用でき ると考えられる。

\section{1. 自由振動解析}

まず，固定荷重の影響を考慮した自由振動解析を行い，ドームの振 動特性を把握した。なお,この解析に限り,ドーム全体を解析領域とし た。表 1 はドームの 1 次〜 7 次の固有円振動数と質量マトリクスに関し ての正規化されたモードに対する刺激係数を示し, 図 3 は上下 $(\mathrm{Z})$ 方 向刺激係数の大きい 2 モードのモード形を示している。以後, 固有 3 次 モードを上下 1 次モード, 固有 7 次モードを上下 2 次モードと呼ぶこ とにする。固有振動モードは図 3 に示したように，上下 1 次モードは 中央節点のみが大きく摇れ, 上下 2 次モードは周辺節点が大きい振幅 を持つモードとなっている。1 次モードと 2 次モードを比べると, 2 次 モードの方が刺激係数が大きくて，励起されやすいと考えられる。

表 -1 : 固有円振動数および刺激係数

\begin{tabular}{|c|c|c|c|c|}
\hline & 固有円振動数 & \multicolumn{3}{|c|}{ 刺激係数 } \\
\cline { 3 - 5 } 次数 & $\mathrm{rad} / \mathrm{sec}$ & $\mathrm{X}$ & $\mathrm{Y}$ & $\mathrm{Z}$ \\
\hline 1 次 & 23.13 & 0.000 & -0.382 & 0.000 \\
2 次 & 23.13 & -0.382 & 0.000 & 0.000 \\
3 次 & $\underline{23.29}$ & 0.000 & 0.000 & 0.426 \\
4 次 & 23.38 & 0.000 & 0.000 & 0.000 \\
5 次 & 23.41 & 0.000 & 0.000 & 0.000 \\
6 次 & 23.41 & 0.000 & 0.000 & 0.000 \\
7 次 & $\underline{29.13}$ & 0.000 & 0.000 & -1.837 \\
\hline
\end{tabular}

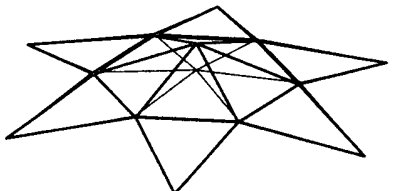

上下 1 次

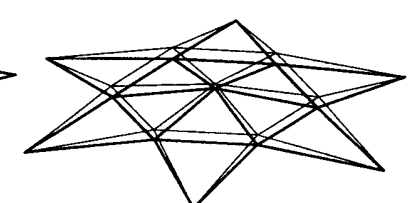

上下 2 次

\section{2. 静的解析} 図ー3: 固有モード

\section{2 .1 等分布荷重による解析}

図 4 は等分布鉛直荷重に対する静的解析によるドームの荷重一変位 曲線を示している。横軸は各節点の鈶直変位で, 縦軸 lambda は固定
荷重に対する分布荷重の倍率である。図 4 に示したように，本モデルは 座屈後急激な耐力低下を起こすことが特徵として挙げられる。図 5 に 式 (4) に基づいて求めた吸収エネルギーを示す。横軸は頂点の鈶直変位 である。吸収エネルギーは変位の増加とともに上昇し, 最大值に至った 後, 変形の進行に伴い减少する。図 5 中の最大值 $(\mathrm{Emax}=0.502 \mathrm{t} \cdot \mathrm{m})$ が静的荷重時に自重によるポテンシャルエネルギー以外にドームが吸収 し得る最大エネルギーとなる。

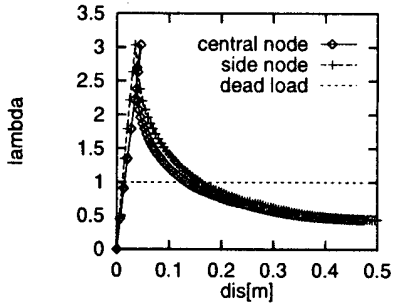

図 -4 :荷重変位曲線 (等分布荷重)

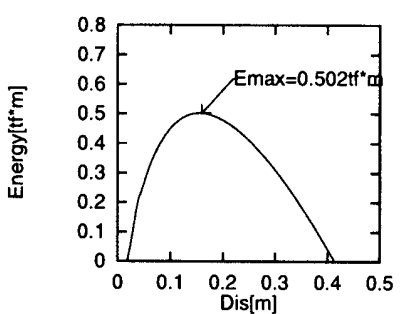

図一 5: 静的吸収エネルギ一
図 6, 図 7 は等分布荷重時の変形性状を示している。図 6 に示した ように, 周辺節点と支持点を聚ぐ部材に最初塑性化が発生し，それらの 部材の塑性化の進展に伴いドーム全体の変形が進み, 図 7 に示すように 周辺節点が落ち込む上下 2 次モードに類似の変形状態で崩壊に至って いる。

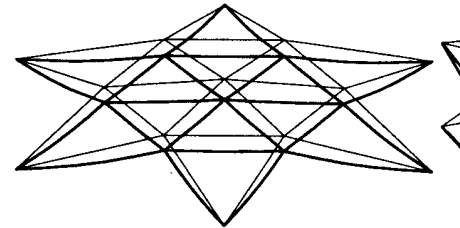

図一 6: 塑性化発生時の変形性状

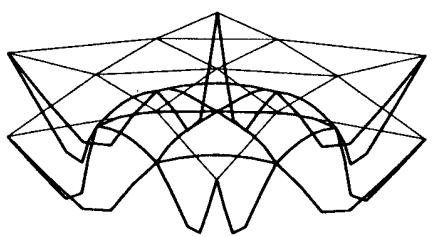

図一 7: 崩壊時の変形性状

\subsection{2 モード比例型分布荷重による解析}

本節では，上下自由振動モードに比例して荷重分布を設定し，等分布 荷重時と最大吸収エネルギーを比較する。ここで，モードに比例する荷 重ベクトル $\left\{F_{i}\right\}$ はモードベクトル $\left\{u_{i}\right\}$ に比例し，かつ全荷重 $\sum\left\{F_{i}\right\}$ が全固定荷重 $\sum\left\{P_{i}\right\}$ を一致するように算定される。図 8 はこのよう にして算定された上下 1 次モードおよび 2 次モードに比例する荷重分 布を表している。

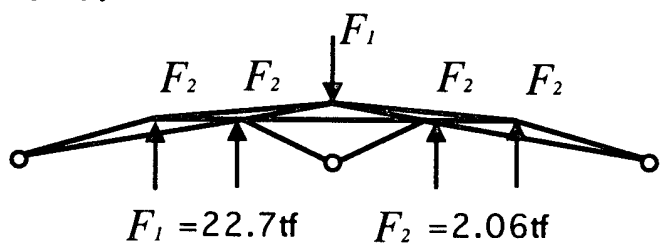

上下 1 次モード

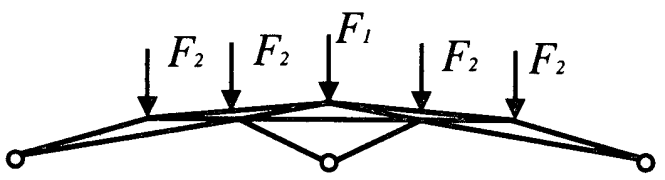

$$
\begin{gathered}
F_{1}=1.66 \mathrm{tf} \quad F_{2}=5.55 \mathrm{tf} \\
\text { 上下 } 2 \text { 次モード } \\
\text { 図-8: モード比例型分布荷重 }
\end{gathered}
$$

図 9，10 にモード比例型分布荷重による解析結果を示す。ここでは, 自重レベルまで等分布荷重を載荷した後, 各モードに比例する分布荷 重を与え，等分布荷重の場合と同様に構造物の吸収エネルギーを計算 している。等分布荷重の場合と同じょうに, 吸収エネルギーが変位の増 加とともに上昇し, 最大レベルを越えると変形の進行に伴い隇少する。 


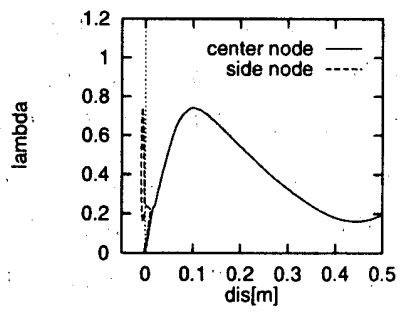

荷重変位曲線

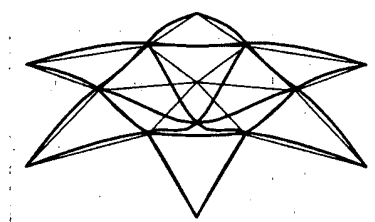

塑性化発生時の変形性状

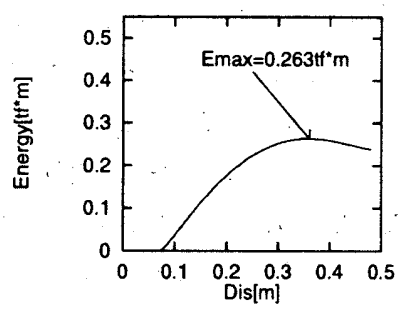

吸收エネルギー

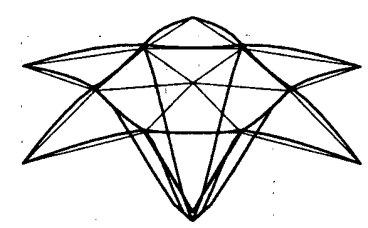

崩壊時の変形性状

図一 9: 上下 1 次モード比例型分布荷重に対する応答

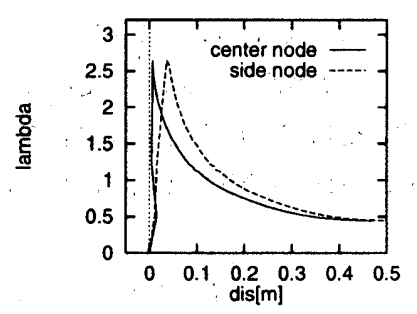

荷重変位曲線

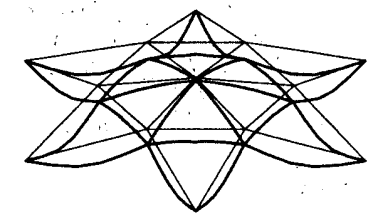

塑性化発生時の変形性状

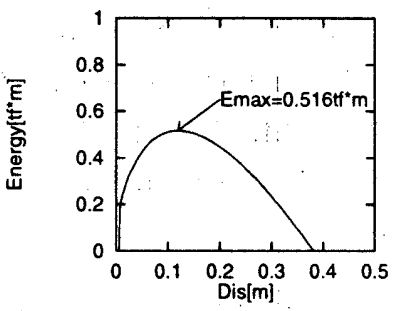

吸収エネルギー

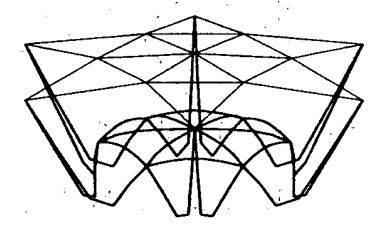

崩壊時の変形性状

図- 10: 上下 2 次モード比例型分布荷重に対する応答 上下 1 次モード比例型荷重分布の場合, 吸収エネルギーの最大值が等 分布荷重の場合の $52.4 \%(\mathrm{Emax}=0.263 \mathrm{t} \mathrm{f} \cdot \mathrm{m})$ で構造物が崩壊した。上 下 2 次モード比例型荷重分布の場合は等分布荷重の場合より少々高い值 $(E \max =0.516 \mathrm{tf} \cdot \mathrm{m})$ で崩塤した。崩塤時の変形性状を比較すると, 上 下 1 次モード比例型荷重の場合は中央節点と周辺節点を慗ぐ部材に最 初塑性化が発生し，それらの部材の塑性化に伴い周边節点付近に塑性七 ンジを生じ崩壊に至るのに対し，上下 2 次モード比例型荷重の場合は等 分布荷重と類似な崩壊性状を示している。従って,ドーム状構造物の場 合は，平板立体トラスとは異なり，崩壊時の変形性状によって吸収エネ ルギーの值が異なってくることが分かる。

\section{3. 動的解析}

本節では，ラチスドームの動的解析を行い，動的崩壊時の吸収エネル キーと静的崩塤時の吸収エネルギーを比較する。にここでいう動的崩塤 は変位がある限界点を越える発散する見象であり，笅密には動的不安定 之呼ぶベきものである。) 入力外乱として正弦波，ハバントリミテッドホ ワイトノイズおよび実地震波を与えた場合について考察する。それぞれ の入力加速度波形とフーリエスペクトルを図 11 に示す。なお；正弦波 については円振動数を $20 \sim 32 \mathrm{rad} / \mathrm{s}$ の範囲で変化させ, 最大加速度 a が 0.2G，0.4G，1Gになるように正規化して用いた。バンドリミテッ ドホワイトノイズの場合は，バンド領域が $0 \sim 25 \mathrm{rad} / \mathrm{s}$ (上下 1 次固有振

動数付近) および $20 \sim 35 \mathrm{rad} / \mathrm{s}$ (上下 1 次および 2 次固有振動数が含ま れる領域) の 2 種頪を設定し，最大加速度 a が $0.2 \mathrm{G} ， 0.4 \mathrm{G} ， 1 \mathrm{G}$ にな るように正規化して用いた。実地震波については，1995 年兵庫県南部 地震の神戸海洋気象台における記録波の上下成分を採用し, 最大加速度 $\mathrm{a}$ が $0.1 \mathrm{G} ， 0.2 \mathrm{G}$ および実最大加速度になるように正規化して用いた。

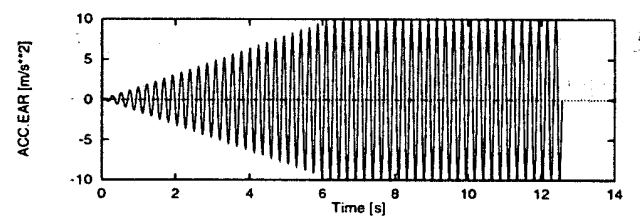

正弦波入力時刻歴波形
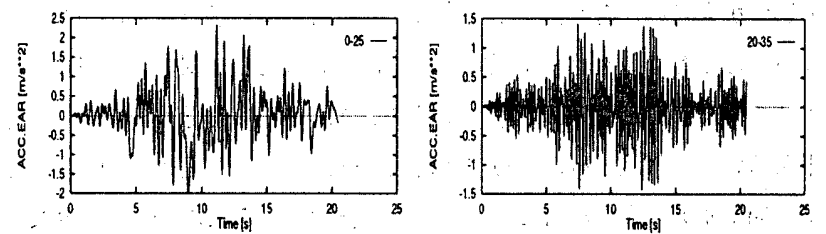

時刻歴波形
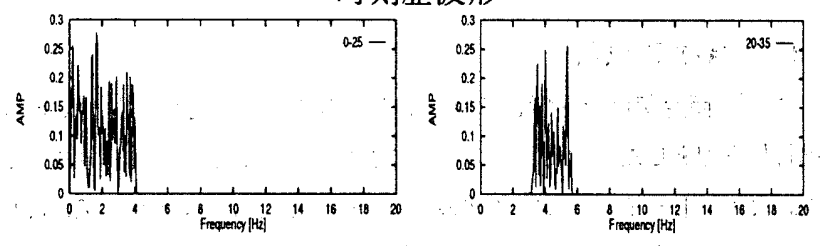

フーリエスペクトル

$\omega=0 \sim 25 \mathrm{rad} / \mathrm{s}$ $\omega=20 \sim 35 \mathrm{rad} / \mathrm{s}$

バンドリミテットホワイトノイズの入力波
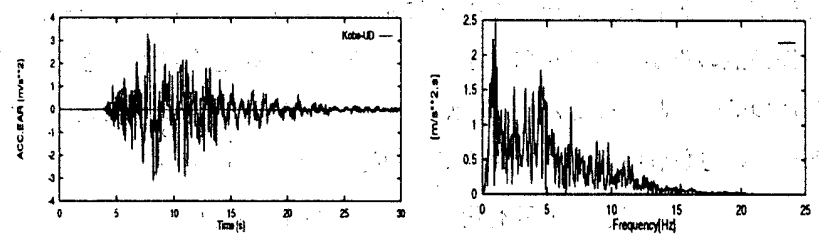

時刻歴一フーリエスペクトル

実地震波入力波形 (Kobe UD)

\subsection{1 正弦波による解析}

図一 11: 入力加速度波形

図 12, 図 15 に上下 1 次および 2 次固有振動数に近い振動数の正弦 波による変位応答を示し，図13，図16にそれぞれの時刻歴吸収エネル ギーを示す。図に示したように， $\omega=21 \mathrm{rad} / \mathrm{s}$ の正弦波加振では低レベ ル入力 $(\mathrm{a}=0.2 \mathrm{G}, 0.4 \mathrm{G})$ に対して部材の塑性化が生じず; 高レベル入 力 $(\mathrm{a}=1.0 \mathrm{G})$ に对して振幅が增大し一気に崩壊まで至っている。崩壊時 の吸収エネルギー $(\mathrm{Emax}=0.998 \mathrm{tr} \cdot \mathrm{m})$ が静的解析によって得られた吸 収エネルギーの最大值 $(\mathrm{Emax}=0.263 \mathrm{tf} \cdot \mathrm{m})$ に比べてかなり大きいこと が分かる。 $\omega=28 \mathrm{rad} / \mathrm{s}$ の正弦波加振では低レベル入力に対しても部材 の塑性化が生じ， $a=1.0 \mathrm{G}$ の時崩壊を生じている。吸収エネルギ一の時 刻歴を見ると，各入カレベルに対して，塑性化の発生時の值がほほ同じ であり, 崩壊時の吸収エネルキー $(\mathrm{Emax}=0.529 \mathrm{tf} \cdot \mathrm{m})$ が静的解析の場 合 $(E \max =0.516 \mathrm{if} \cdot \mathrm{m})$ に近い結果となっている。

$\omega=21 \mathrm{rad} / \mathrm{s} と \omega=28 \mathrm{rad} / \mathrm{s}$ の 種類の正弦波加振 $(\mathrm{a}=1 \mathrm{G})$ による 時刻歷変位応答波形の全継続時間を 2 秒間隔に分け; 各区間の応答につ いて振動モードの抽出を行った結果が图 14, 図17に示されている。抽 出 1 次モードにういては， $\omega=21 \mathrm{rad} / \mathrm{s}$ の正弦波加振の場合; “最初弹性 


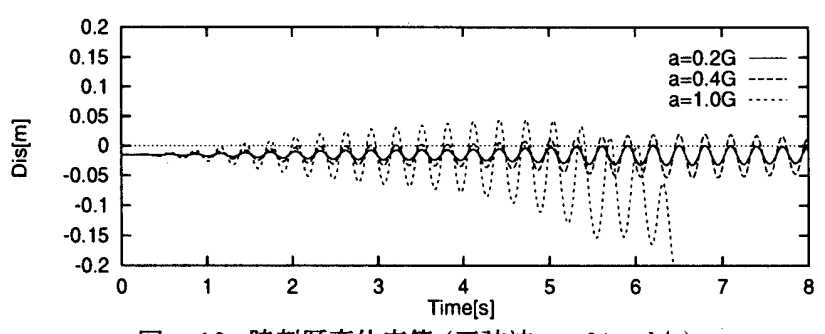

図-12: 時刻歷変位応答 $($ 正弦波 $\omega=21 \mathrm{rad} / \mathrm{s}$ )

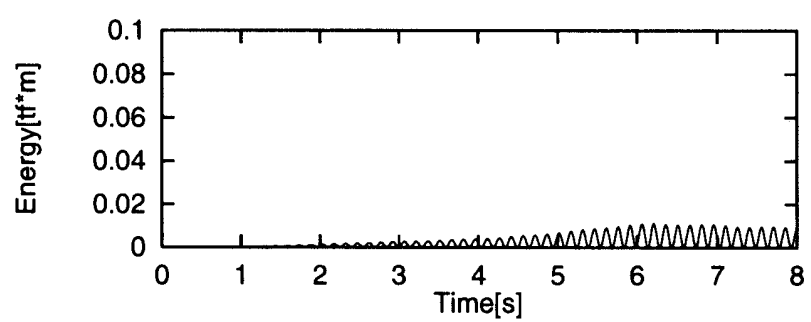

入力最大加速度 $\mathrm{a}=0.2 \mathrm{G}$

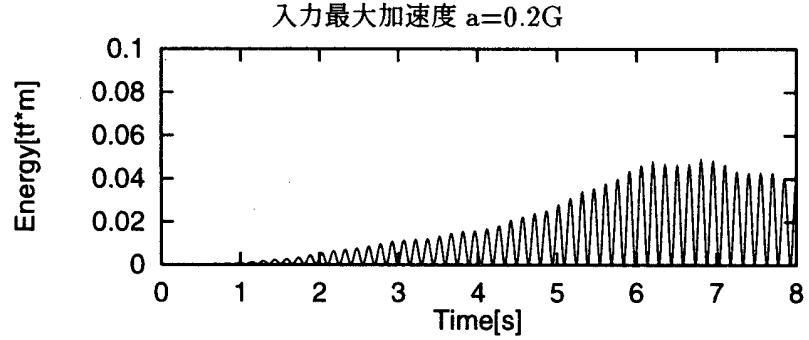

入力最大加速度 $\mathrm{a}=0.4 \mathrm{G}$

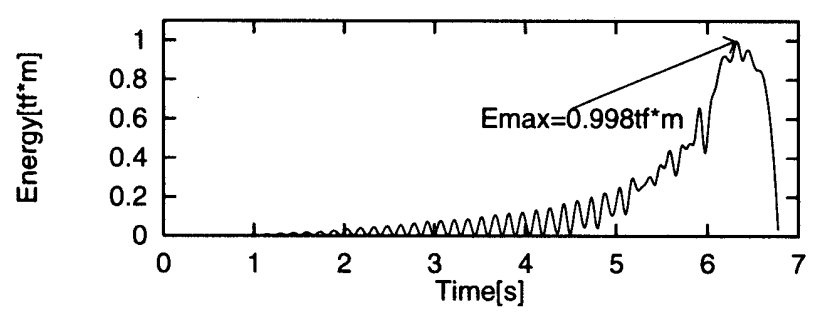

入力最大加速度 $\mathrm{a}=1.0 \mathrm{G}$

図- 13: 時刻歴動的吸収エネルギー (正弦波 $\omega=21 \mathrm{rad} / \mathrm{s})$
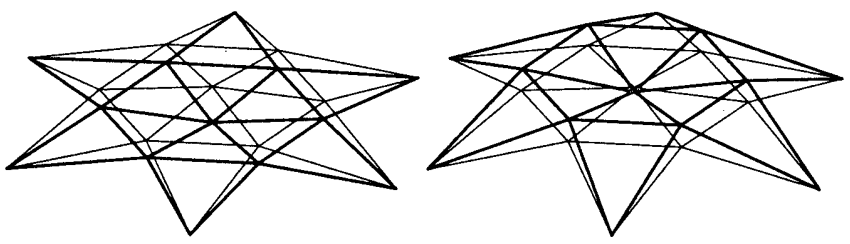

$0 \sim 2(\mathrm{~s})$
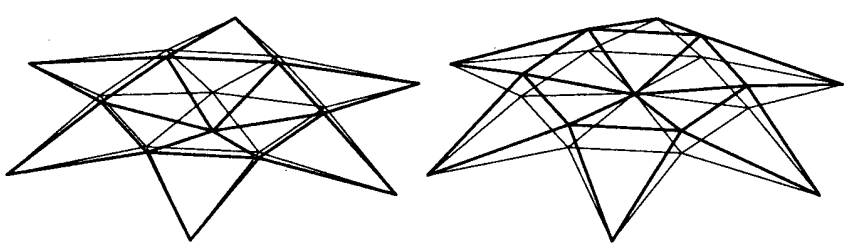

$2 \sim 4(\mathrm{~s})$
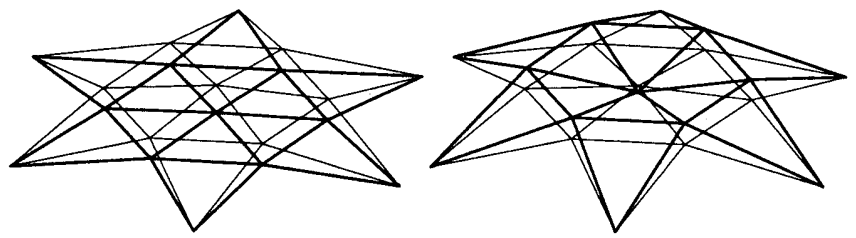

$4 \sim 6(\mathrm{~s})$

一次モード

二次モード

図-14: 振動モードの推移 (正弦波 $\omega=21 \mathrm{rad} / \mathrm{s}$ )

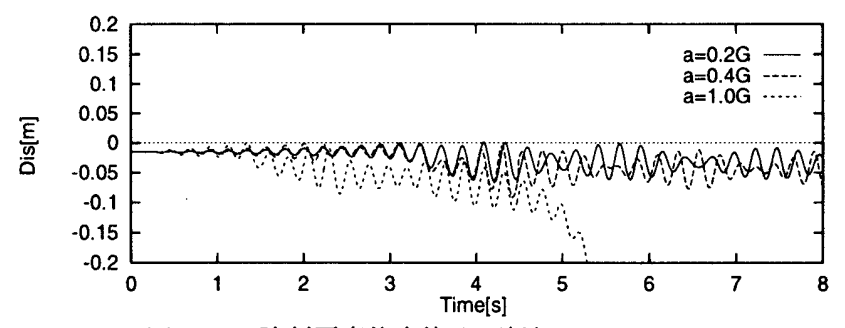

図-15: 時刻歴変位応答 $($ 正弦波 $\omega=28 \mathrm{rad} / \mathrm{s}$ )
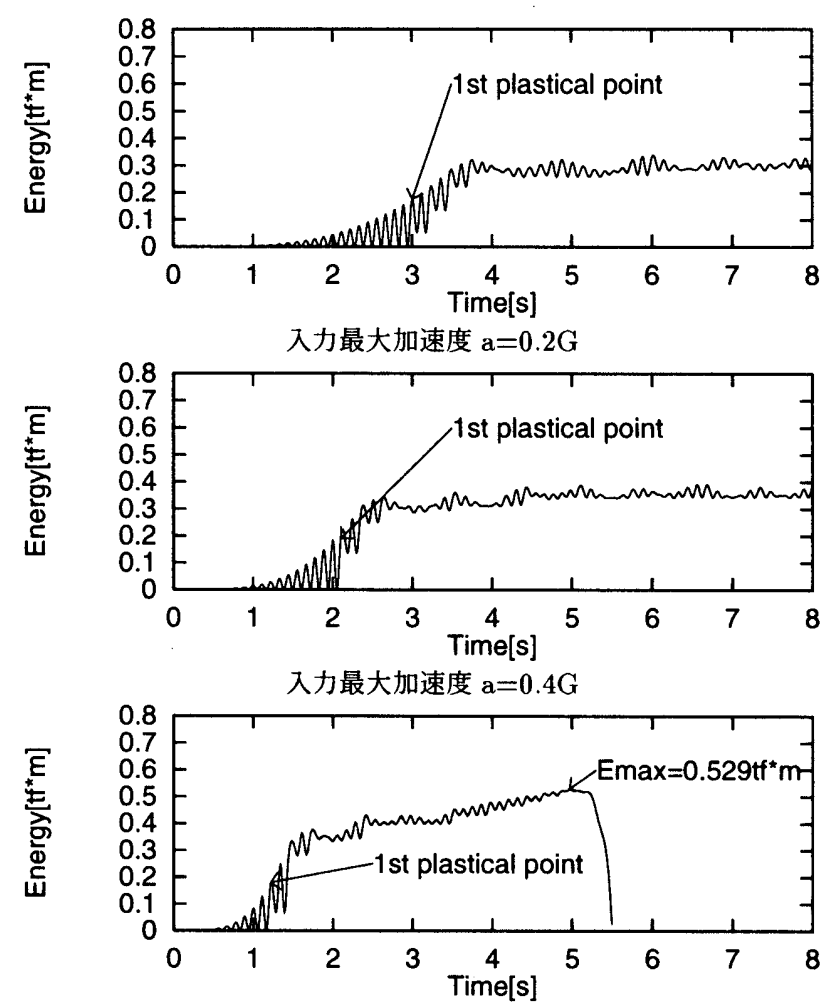

入力最大加速度 $\mathrm{a}=1.0 \mathrm{G}$

図一 16: 時刻歴動的吸収エネルギー (正弦波 $\omega=28 \mathrm{rad} / \mathrm{s}$ )
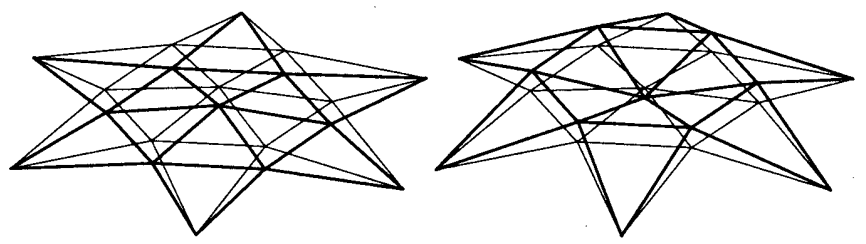

$0 \sim 2(\mathrm{~s})$

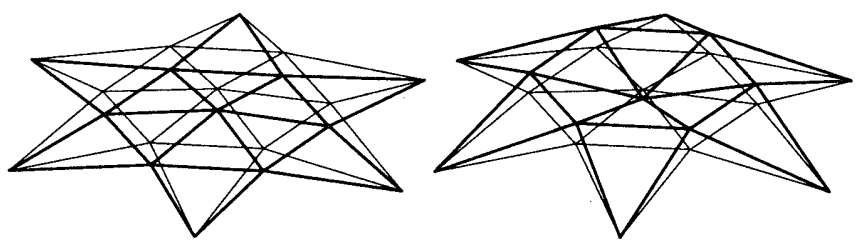

$2 \sim 4(s)$

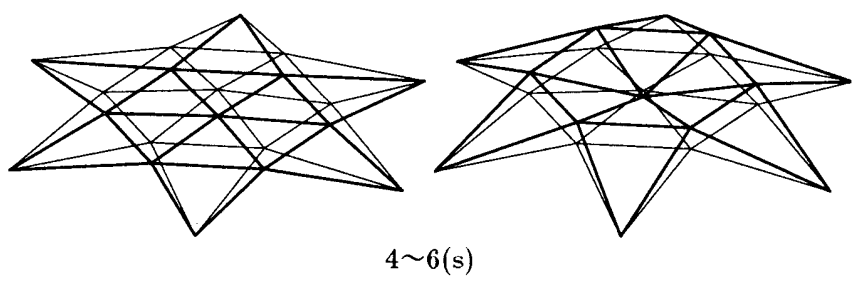

$$
\text { 一次モード 二次モード }
$$

図-17: 振動モードの推移 (正弦波 $\omega=28 \mathrm{rad} / \mathrm{s}$ ) 
1 次モード成分が現れ $(0 \sim 2 \mathrm{~s})$, 振動が大きくなると共に部材の塑性化 により徐々に弾性 2 次モード成分が含まれるようになり $(2 \sim 4 \mathrm{~s})$, さら に塑性化の進展と共に弾性 2 次モードが支配的になり (4〜6s), 崩壊に 至うている。ちなみに, 弾性 1 次モードと 2 次モードの奇与率は 2 $4 \mathrm{~s}$ で 1:0.6, 4 6s で 1:2.9 である。 $\omega=28 \mathrm{rad} / \mathrm{s}$ の正弦波加振の場合 は, 各時間区間において弾性 1 次モードと 2 次モードの奇与率は $1: 3$ 前後であり, 振動モードの変化は現れない。一方, 抽出 2 次モードに ついては, いずれの時間帯においても弾性 2 次モードに類似した変形 になっている。

以上の結果より，振動モード形状が大きく変化せず崩壊に至る場合 は, 塑性化の進展により振動モードが変化して崩壊に至る場合より吸収 エネルギーが低く崩壊しやすいことが分かる。さらに, そのモード形状 が静的な変形性状に類似する場合は, 動的吸収エネルギーは静的吸収工 ネルギーに近い值になり, 静的解析により動的崩壊を推定することが可 能であると考えられる。

図 18 は, 正弦波の振動数に対する動的最大吸収エネルギーの関係を 示したものである。図中の四角形の黒点が崩壊した場合を示している。 振動数の領域は図に示すように大きく 3 区域に分けられる。第 1 は振 動モードが変化する区域, 第 2 は振動モードが変化しない区域, 第 3 は 自由振動モードが卓越する振動数域から外れ，崩壊が生じなかった区域 である。第 1 領域では, ラチスドームのように非線形性が強い構造物に おいては, 振幅の増大によりモードが変化し, 吸収エネルギーもそれに 伴って增大すると考えられる。第 2 領域では，振動モードは変化せず, 上下 2 次モードに類似した変形になっており, 崩壊時の動的吸収エネル ギーは上下 2 次モード比例型荷重による静的吸収エネルギーに近い値 になっている.

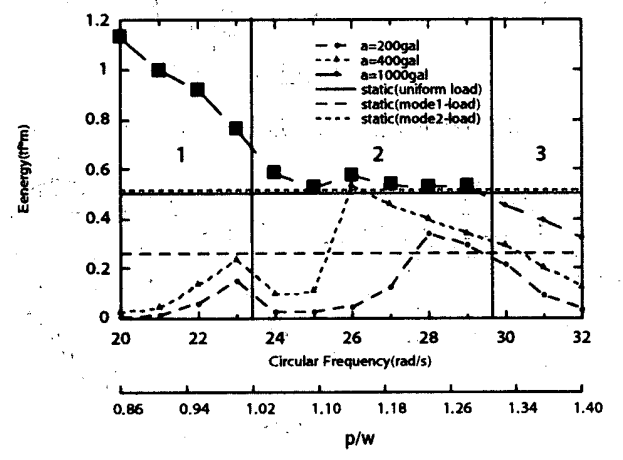

図ー18: 正弦波による吸収エネルギー

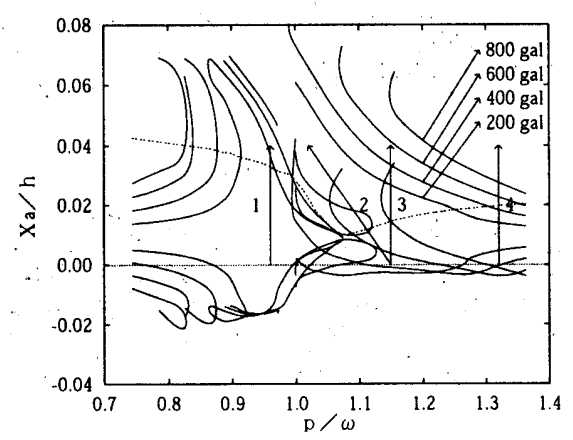

図- 19: 共振曲線 (中央節点)

比較のため, 定常振動解析に基づいて描かれた共振曲線 11）を図 19 に示す。図中の絠軸はライズ $h$ で無次元化された中央節点の変位を, 横
軸は加振振動数 $p$ と弾性 1 次固有振動数 $\omega$ の比を示している。図に示 したように，本解析モデルにおいては，振動数領域が性質の異なる2つ の共振領域すなわち固有振動数の低次側と高次側に分けられる。低次側 を励起する振動数の正弦波を入力する場合は, 図中矢印 1 の経路により 安定領域を越え変形が進み崩壊に至るが，安定領域を越えるために多く のエネルギーを吸収すると考えられる。それに対して，高次側に近い振 動数の正弦波を入力すると, 図中矢印 3 の経路により共振領域の範囲内 で変形が進み崩壊に至るため, 低次側と比べて崩壊時の吸収エネルギー が小さくなると推察される。さらに高振動数の場合は，図中矢印 4 に示 したように共振曲線と外れるため, 崩壊に至るにはかなり大きな入力加 速度が必要となる。これらの傾向は図 18 に示す 3 つの領域と対応して いることが分かる。

\section{3 .2 ホワイトノイズおよび実地震動による解析}

図 20,21 はバンドリミテッドホワイトノイズによる解析結果の一部 を示している。 $\omega=0 \sim 25 \mathrm{rad} / \mathrm{s}$ のホワイトノイズ加振の場合は最大入 力加速度が $1.0 \mathrm{G}$ になると崩壊し，この時の動的吸収エネルギーの最大 值は $0.469 \mathrm{tf} \cdot \mathrm{m}$ である。 $\omega=20 \sim 35 \mathrm{rad} / \mathrm{s}$ のホワイトノイズ加振の場合 は最大入力加速度が $0.2 \mathrm{G}$ でも崩壊し，この時の動的吸収土ネルギーの 最大値は $0.42 \mathrm{tf} \cdot \mathrm{m}$ である。振動モードについては，いずれも上下 2 次 モードが支配的であり，塑性化によるモードの変化は見られない。図 22 は実地震波 (神戸海洋気象台記録波) による動的挙動を示している。ホ ワイトノイズの場合と同じょうに，上下 2 次モードが支配的であり，塑

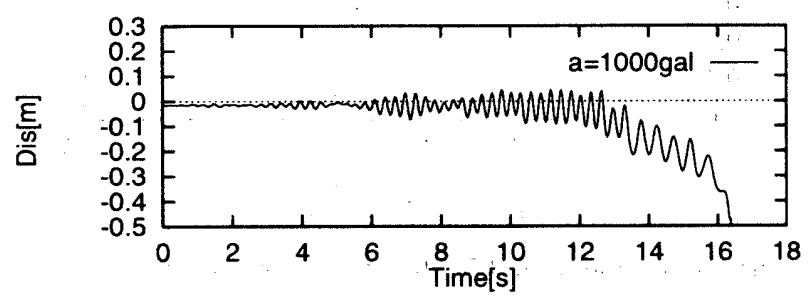

時刻歴変位応答
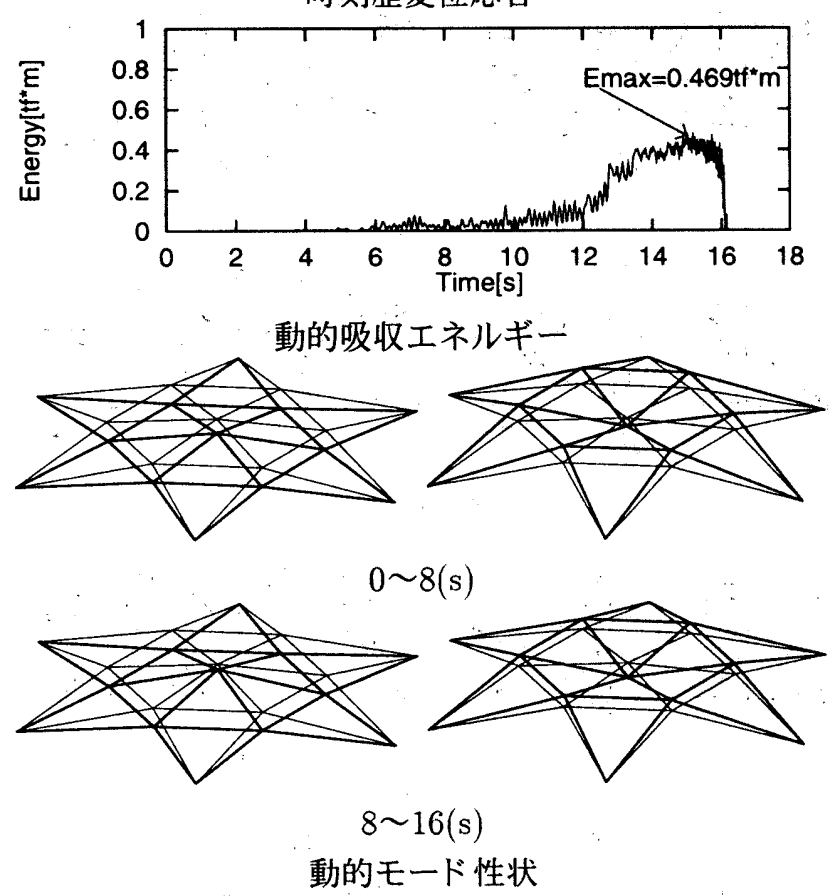

図ー 20: ホワイトノイズによる動的挙動 $(\omega=0-25 \mathrm{rad} / \mathrm{s}, a=1.0 \mathrm{G})$ 


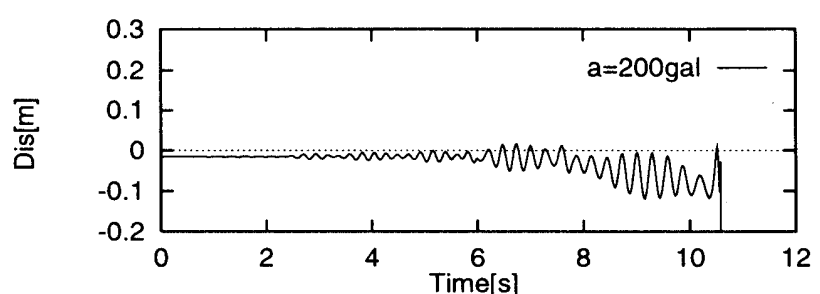

時刻歴変位応答

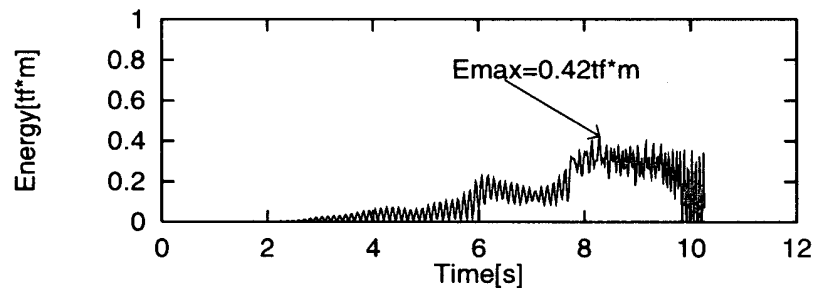

動的吸収エネルギー

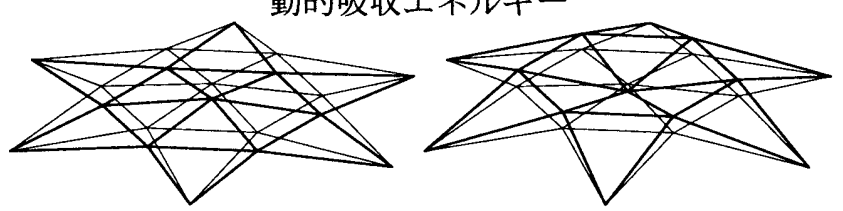

$0 \sim 8(\mathrm{~s})$

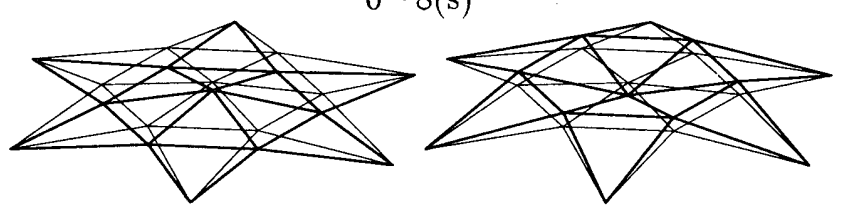

$8 \sim 16(\mathrm{~s})$

動的モード性状

図ー 21: ホワイトノイズによる動的挙動 $(\omega=25-35 \mathrm{rad} / \mathrm{s}, \quad \mathrm{a}=0.2 \mathrm{G})$

性化によるモードの変化は生じていない。この時の動的吸収エネルギー の最大值は 0.403tf $\mathrm{m}$ である。なお, El-Centro 1940 地震波による解 析も行ったが，その地震波の卓越振動数域は今回の解析モデルの卓越振 動数域を外れ, 図 18 の第 3 域に入ったため, 最大入力加速度 $3 \mathrm{G}$ で ドームが崩壊し，その時の吸収エネルギーは $0.59 \mathrm{tf} \cdot \mathrm{m}$ であった。

ホワイトノイズや実地震動の場合は, 入力波形に多数の周波数成分 が含まれるため, 構造物の最も振動しやすい上下 2 次モード (刺激你数 が大きいモード) が励起され，図 19 の矢印 2 の経路で高次側共振曲線 の背骨曲線に沿いながら変形が進み, 最も崩壊しやすいパターンで崩壊 したと考えられる。そのため崩壊時の動的吸収エネルギーは上下 2 次 モード比例型荷重による静的吸収エネルギーを下回る結果となったと推 察される。

\section{4. 結び}

偏平ドーム状空間骨組構造物の力学特性を有する解析モデルについ て，幾何学的非線形性及び材料的非線形性を考慮した静的および動的時 刻歷応答解析を行い, 構造物の弾塑性崩壊挙動について考察した。特に 吸収エネルギーの観点から, 構造物の崩壊性状の変形性状への依存性に ついて分析し, ドーム状構造物と平板立体トラスの相違を明らかにし た。ただし，ここでの検討は一つの特殊な形状のドームに関するもので あり,一般的な結論を得るには, 今後形状や荷重条件, 境界条件などが 異なるドームについて多面的な検討が必要である。

本研究で得られた主な知見を以下に要約する。

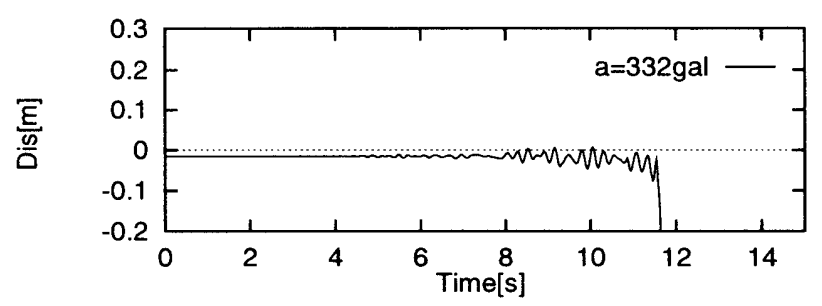

時刻歴変位応答

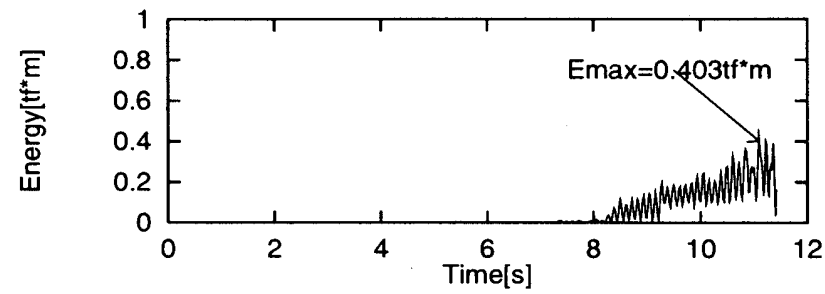

動的吸収エネルギー

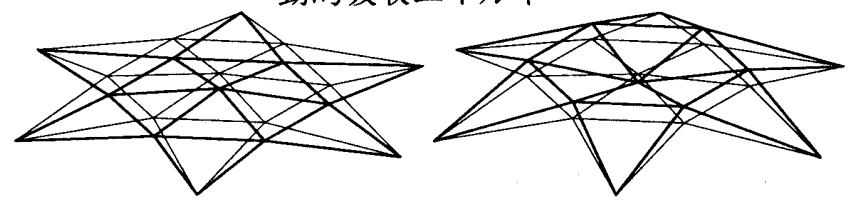

$0 \sim 8(\mathrm{~s})$

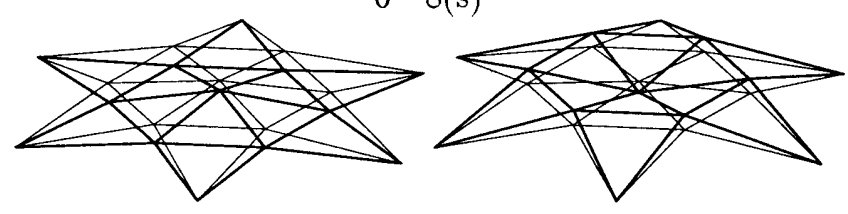

$8 \sim 16(\mathrm{~s})$

動的モ一ド性状

図-22: 実地震動による動的挙動 (Kobe UD)

1.ドーム状構造物の場合は，平板立体トラスのように等分布荷重と モード比例型分布荷重による崩壊時の静的吸収エネルギーが必ずし も一致せず, 崩壊時の変形性状により異なる。

2. 構造物の動的吸収エネルギーは, 励起される振動モードにより異な る。崩壊時の吸収エネルギーは入力加速度の最大値のみならず, 入 力波形の周期特性とも関連がある。

3. 構造物の静的崩壊時および動的崩壊時の吸収エネルギーはともに 有限值であり，変形性状が類似する場合は両者の吸収エネルギーの 最大値は近い值となる。すなわち, 振動モ一ドが変化せず, 静的な 変形性状に類似の振動モードが励起される場合は, 動的吸収エネル ギーは静的吸収エネルギーに近い值になり, 塑性化の進展により振 動モードが変化すると, 静的吸収エネルギーと大きく異なる。

4. 実地震波やホワイトノイズ波の場合は, 構造物の最も振動しやすい モードが励起される。崩壊時の動的吸収エネルギーはモード比例型 荷重による静的吸収エネルギーを下回っており, 平板立体トラスの ように静的吸収エネルギーが必ずしも動的吸収エネルギーの下限值 を与えるとは限らない。

以上のように, ドーム状構造物の場合は, 崩壊時の動的吸収エネル ギーが励起される振動モードによって異なり，モード比例型荷重による 静的吸収エネルギーが必ずしもその下限值を与えるとは限らず，平板立 体トラスに対して多田ら ${ }^{9)}$ が得た結論はドーム状構造物には直接適用 できないことが明らかとなった。今後, 合理的な設計用地震荷重分布を 
設定するためには，構造物の崩壊時の変形性状を把握することが重要で あり，塑性化によるモード形の推移や非線形共振曲線との関連を分析す る必要があると考える。

\section{蓉文献}

1）日本建築学会 : シェル・単層ラチス構造の振動解析一地䢅，風応答と動的安 定一，丸善, 1993

2）国枝治郎：上下地震動を受ける球形ドームの応答解析，京都防災研究所年報， 第 26 号, B-1, pp.1-11, 1983

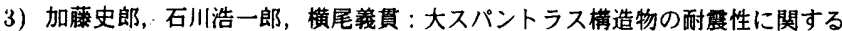
研究，上下地震動を受ける平行弦トラスばりの耐㙰性について，日本建築学 会構造系論文報告集，第 360 号, pp. 64-74, 1986

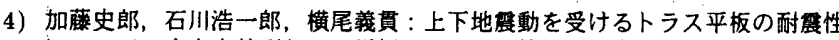
について：直交交差型トラス平板についての検尉，日本建築学会構造系論文 報告集，第 370 号，pp. 60-67, 1986

5）和田章, 向秀元：一方向大スパン複層円筒トラス構造物の地震応答解析，日 本建築学会構造系論文報告集，第 413 号，pp. 87-95，1990
6）石川浩一郎，加藤史郎：上下地霞動を受ける二層立体ラチスドームの耐震性に 関する研究，日本建築学会構造系論文報告集，第 447 号, Pp. 79-88, 1993

7）加藤史郎，向山洋一，植木隆司：高ライズドームの地厝応答性状，日本建築 学会檴造系論文報告集，第 442 号, pp. 101-109, 1992

8) ·加藤史郎, 庄村昌明, 向山洋一: 水平と鈶直地磭動を受ける大スパン単居ラチ スドームの応答性状と崩壤加速度に関する研究，日本建策学会構造系論文報 告集, 第 477 号; pp. 87-96, 1995

9）多田 元英, 米山隆也：建築物の屋上に設圈された 2 居立体トラスの铬直地 砖応答, 日本建学学会構造系論文報告集, 第 452 号, pp. 77-86, 1993

10) Hangai, Y. and Kawamata, S.: Perturbation Method in the Analysis of Geometrically Nonolinear and Stability Problems, Advancement in Computational Mechanics in Structural Mechanics and Design, pp.473-489, UAH press, 1972.

11）萩原伸幸：材料および幾何学的非線形性を伴う構造物の定常解と動的非線形 挙動に関する研究, 名古屋大学学位論文, 1998

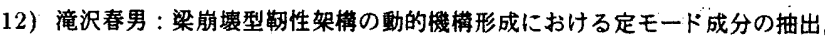
構造工学論文集, Vol.36B，pp. 245-258, 1990

（1999年 7 月 9 日原稿受理，1999年12月20日採用決定） 